\title{
Transparencies: Introduction
}

\section{Kerry-Jane Wallart}

\section{(2) OpenEdition}

\section{Journals}

Electronic version

URL: https://journals.openedition.org/ces/5388

DOI: 10.4000/ces.5388

ISSN: 2534-6695

\section{Publisher}

SEPC (Société d'études des pays du Commonwealth)

\section{Printed version}

Date of publication: 1 September 2012

Number of pages: 5-7

ISSN: 2270-0633

\section{Electronic reference}

Kerry-Jane Wallart, "Transparencies: Introduction", Commonwealth Essays and Studies [Online], 35.1 | 2012, Online since 18 April 2021, connection on 23 July 2021. URL: http://journals.openedition.org/ ces/5388; DOI: https://doi.org/10.4000/ces.5388

\section{(c) (i) $(9)$}

Commonwealth Essays and Studies is licensed under a Licence Creative Commons Attribution - Pas d'Utilisation Commerciale - Pas de Modification 4.0 International. 


\section{Introduction}

It may seem unexpected, even paradoxical and possibly absurd to dedicate a volume of literary scholarship to the concept of transparency. Indeed the latter describes a visual phenomenon that hardly accommodates the obstacle that language necessarily constitutes. Such an obstacle is reinforced by the departure that literature makes by definition from standard language. If the realm of vision is well-known to weave fascinating patterns with literature it still seems that the critic tends to side with opacity, not transparency. And yet fiction constantly stages, represents and fantasizes its own encounter with reality, associating perception with pellucidity. The gap between signifier and signified can thus be read as a journey that is similar to that of the eye when traversing a screen. It transposes and translates our world "through the looking-glass" of textuality in a rather Carrollian way.

Transparency poses further questions in the case of postcolonial literatures. The latter are written palimpsestically in the language of the former Empire, they are couched on the surface (or screen?) of other languages and cultures that remain partly indomitable by the words of the British Isles. Transparency becomes a double illusion but also an interrogation of the conditions of existence of those very texts that are, if only geographically, necessarily marginalized. Transparency may have to be seriously distrusted if one is to avoid a phenomenon of domestication as described by Homi Bhabha:

In fact the sign of the "cultured" or the "civilised" attitude is the ability to appreciate cultures in a kind of musée imaginaire; as though one should be able to collect and appreciate them. Western connoisseurship is the capacity to understand and locate cultures in a universal time-frame that acknowledges their various historical and social contexts only eventually to transcend them and render them transparent. (208)

The notion of diversity is charged here with being heir to the Enlightenment ideal of universalism behind an apparent relativism. In order to transcend such apparent irreducibility of cultures, Bhabha has coined the phrase of "third enunciation" and described it as a horizon, another space "which enables other positions to emerge" (211) in a spirit of difference, not diversity. Such a space is a metaphor for the voice of the writer, otherwise designated as an "enunciation" and it will come as no surprise that interrogations around the notion of enunciation swarm in every one of the ten articles presented in the volume. It is analyzed by all authors in terms of blurring, of differentiation and otherness, of instability and ultimately, opacity. Again, one veers towards the opposite of transparency. As a result, the idea of penetration expressed by the prefix "trans-" leads the investigations which deploy themselves in this volume to confront the artificiality and necessary obfuscation underlying the alleged transparency of the texts under scrutiny.

The two opening papers call into question the tradition of nineteenth- and early twentieth-century realism and its apparent claim to representational transparency. In both cases realism is actually yoked together with references that break the illusion from the very start. In A Suitable Boy, Vikram Seth rewrites Jane Austen and George Eliot in 
an Indian, post-Independence context. Mélanie Heydari-Malayeri recalls the definition of mimicry by Bhabha to posit such transparent transposition as both a resemblance and a menace. She argues for a reconsideration of Seth's novel, one which has raised little scholarly attention, in the light of postcolonial attitudes. André Dodeman reads the influence of Modernism on Morley Callaghan as a Rousseauean attempt at clarity of vision. Intelligibility is upstaged in The Loved and the Lost in social but also aesthetic terms and its quest becomes the topic and structure of the novel. In those two novels the lending of a semblance of reality turns out to be both an illusion and an ideological stance.

Four papers on Janet Frame's works then investigate her complex and undeniable distrust of transparency. Pascale Tollance scrutinizes the encoding and impossible decoding of riddles, enigmas and secrets in The Lagoon and Other Stories. By looking at the "opposition and distribution between the visual and the verbal" she is led to draw fascinating conclusions as to the devouring metaphor in those short stories and the intertext of such tales as "The Gingerbread Man." Kathie Birat singles out the same corpus and focuses on questions of orality in their relation with the shaping of our perception of reality. In a daring reading of the emulation of childish diction found in Frame's stories, her paper goes to show that orality is transcribed on the level of sight and vice versa, and that our speech as well as that of others actually both transcribe and create our vision. The analysis draws on Jakobson and Dolar and reads the presence of nursery rhymes in a brilliantly convincing way. Alice Braun substitutes the arrow through transparency with what she calls a "line of flight" by bringing together the novel Living in the Maniototo that stages a novelist and Frame's autobiography. Braun questions the possibility for a writer's autobiographical enterprise to be concerned with anything else than the act of writing, with all the tricks this entails. In a Foucauldian gesture, she links transparency with the positivist obsession with confession that dates back to the seventeenth century and aimed at casting light on deviant sexualities. Héliane Ventura reads "Spirit" as an answer to the metaphysical question of life after death but also as a metatextual reflexion on the reincarnation of the hallowed English Canon texts in the Antipodes - or the "antipathies," as Alice calls them (8). The four essays adopt complementary angles to interrogate the tricks Frame plays on her reader even as she displays representations of "the author's true self" at a second remove. Like Alice in Wonderland, or the Cheshire Cat, the personae in both the novels and the short stories by Janet Frame all but disappear behind a consideration of the validity of language - the possibility for an empty orange marmalade jar still to be labelled "orange marmalade" (8).

My paper on The Blood Knot, a play by Athol Fugard, transposes the question of transparency onto the stage and draws on the Brechtian use of the fable to scrutinize how transposition may be at work to denounce the workings of the South African apartheid regime and to reinvent an immediate shock in front of it. Three papers on Australian literature then hinge on hybridity, a notion which has been used since the earliest postcolonial criticism and is now revisited. Marjorie D'Ambrosio scrutinizes what she calls phenomena of "blurring" in two novels by Brian Castro that have never been compared systematically, Birds of Passage and After China. She shows how categories, origins, genres, tongues and language itself are used as a series of veils in order to diffract meaning and, in its wake, essence. Pilar Rojo Graso's paper underpins a turn to more political concerns as she reads Malouf's An Imaginary Life in the light of Australia's "Reconciliation." She shows that this much criticized and possibly much misread novel 
does stage a colonial Ovid and an oppressed wild Child, echoing the relation between the white settler and the Aborigine, but that such roles are also subject to change. Lastly Salhia Ben-Messahel takes Wonders of a Godless World as a case in point of how fantasy, the Gothic and fairy tales can be recast and transposed as a chronicle of modern Australia. Literary tradition becomes a "mode of concealment," an optical illusion that eventually allows the reader's gaze to see parallels that are no longer obvious - such as the one between natural and human histories. She concludes, as I shall do here, on the "transparency of the imagination" - a direction in which the sum of these essays gazes indeed.

Kerry-Jane WALLART, guest editor

\section{Works Cited}

Внавна, Homi. “The Third Space.” Interview with Jonathan Rutherford. Identity: Community, Culture, Difference. Ed. Jonathan Rutherford. London: Lawrence and Wishart, 1990. 207-21.

Carroll, Lewis. Alice in Wonderland. 1897. New York: Norton, 1992. 